\title{
Mitochondrial and allozyme genetics of two Tasmanian galaxiids (Galaxias auratus and G. tanycephalus, Pisces: Galaxiidae) with restricted lacustrine distributions
}

\author{
J. R. OVENDEN, R. W. G. WHITE \& M. ADAMS* \\ Fish Research Group, Department of Zoology, University of Tasmania, G.P.O. Box 252C, Hobart, Tasmania and \\ ${ }^{*}$ Evolutionary Biology Unit, South Australian Museum, North Terrace, Adelaide, South Australia, Australia
}

\begin{abstract}
Galaxias auratus and $G$. tanycephalus have a restricted distribution in Tasmanian highland lakes and were probably derived from a landlocked population of the diadromous $G$. truttaceus during the last 100,000 years. We have analysed the mitochondrial DNA and the allozyme products of 22 nuclear loci for each lake species. Four mitochondrial DNA haplotypes, defined by $40-42$ six-base restriction sites, were identified amongst $26 \mathrm{G}$. auratus and three haplotypes, defined by 38-39 restriction sites, were found in six $G$. tanycephalus. The evolutionary genetics of reproductive isolation appears to have inflated mitochondrial but not nuclear DNA diversity between the lake species and their hypothesized progenitor, G. truttaceus. The amount of intraspecific mitochondrial and nuclear DNA diversity for $G$. auratus and $G$. tanycephalus is consistent with their having an extended and independent evolutionary history in reproductive isolation.
\end{abstract}

Keywords: allozymes, evolution, Galaxias, landlocking, mitochondrial DNA.

\section{Introduction}

Nucleotide sequence diversity of mitochondrial DNA (mtDNA) between and within closely related animal species provides an excellent record of evolutionary history (Brown, 1985; Wilson et al., 1985; Avise et al., 1987). The mitochondrial genome is particularly useful because mutations are generally passed from mother to offspring (Lansman et al., 1983; Gyllensten et al., 1985) and are never transferred out of lineages by recombination (Avise et al., 1987). In an interbreeding, reproductively isolated population, the rate of lineage loss depends on the variance of family size and individual survivorship to reproductive age (Avise et al., 1984), while the rate of lineage gain depends on the rate of faulty mtDNA replication and repair and stochastic forces associated with oocyte production (Birky et al., 1983).

Mitochondrial DNA analysis has been particularly appropriate for the exploration of evolutionary history within and between closely related freshwater fish species. A relative lack of mtDNA diversity is often the only clue that a bottleneck event (Carson, 1968) may

Correspondence: J. R. Ovenden. have occurred, especially if the event was transitory. For example, 61 Galaxias truttaceus sampled from central Tasmanian lakes were found to represent only two mtDNA lineages compared to the 58 lineages which were found amongst 150 stream fish of the same species (Ovenden \& White, 1990). In the same study, the relatively high amount of nuclear DNA diversity in the landlocked, compared to the stream populations of $G$. truttaceus was deduced to be a natural consequence of their youth. Bermingham \& Avise (1986) and Ovenden et al. (1988) found that the branching order of phylogenies describing mtDNA evolution in populations of Amia, Lepomis and Gadopsis species could be independently verified by the known geological history of their habitats. This was attributed to the pronounced degree of geographical isolation experienced by populations in different catchments.

The Galaxiidae is a family of small scaleless freshwater fish found in Australia, New Zealand, South America and South Africa as well as some small Pacific islands (Berra, 1981). The greatest species diversity occurs in Australia which has 20 species, including 18 endemics, and New Zealand, which has 13 species of which 11 are endemic. In Australia, 15 species are found in Tasmania, 10 of which are restricted to the 


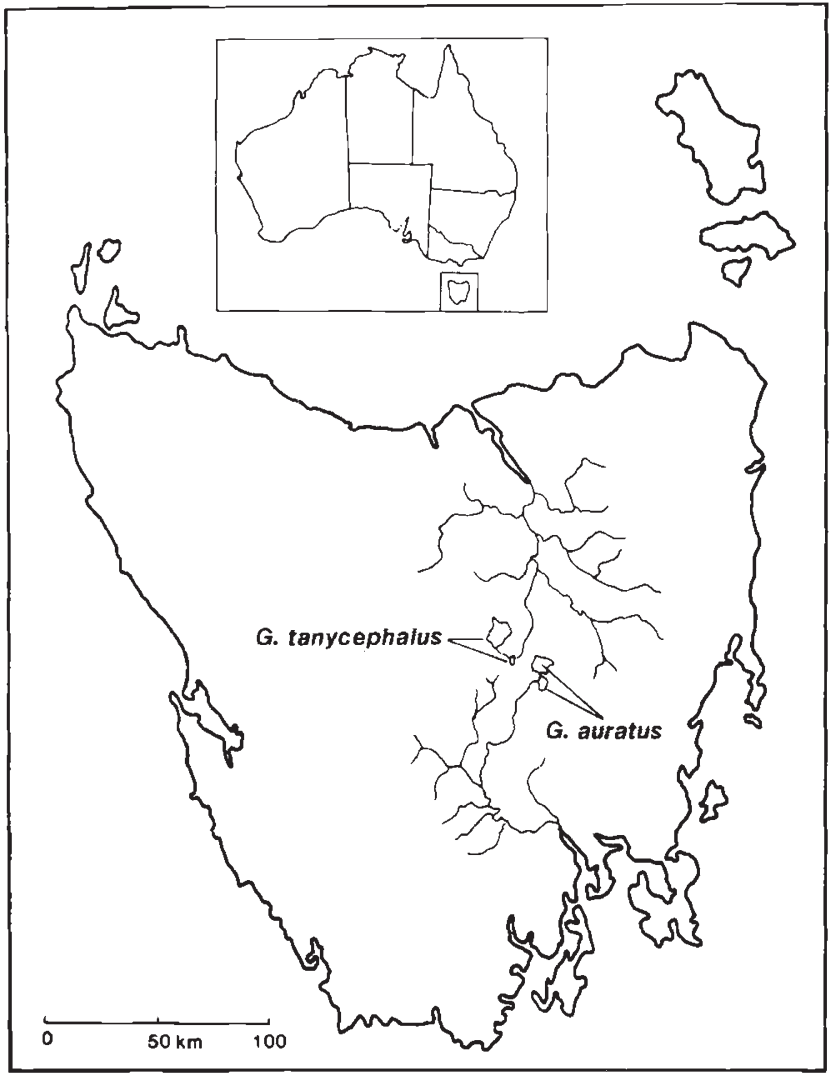

Fig. 1 Distribution of G. auratus (Lakes Sorell and Crescent) and G. tanycephalus (Arthurs and Woods Lakes).

island state (McDowall \& Frankenberg, 1981). The family is represented by diadromous and landlocked freshwater species in riverine and lacustrine habitats.

Three species ( $G$. truttaceus, $G$. auratus and $G$. tanycephalus) form a distinct clade within the genus. This has been confirmed by studies of their morphology (Fulton, 1978; McDowall \& Frankenberg, 1981; Johnson et al., 1983) and karyology (Johnson et al., 1981). G. tanycephalus is found only in Arthurs and Woods Lakes on the Central Plateau of Tasmania, while G. auratus is found only in Lakes Crescent and Sorell. The third species, G. truttaceus, is widespread in coastal drainages in south eastern Australia, as well as in a few landlocked lakes on the Central Plateau. Adult riverine $G$. truttaceus spawn in autumn and the larvae spend the winter at sea before returning to freshwater in spring. Lacustrine $G$. tanycephalus, $G$. auratus and $G$. truttaceus spawn in spring and have an entirely freshwater life cycle (Humphries, 1989).

The derivation of landlocked, entirely freshwater species from inland invading diadromous species is thought to be a major speciating force in the genus
(McDowall, 1972; Andrews, 1976). Accordingly, G. auratus and $G$. tanycephalus are assumed to be landlocked derivatives of the ubiquitous $G$. truttaceus (Fulton, 1978; Humphries, 1989). In a previous study (Ovenden \& White, 1990), the mitochondrial and allozyme genetics of a landlocked population of $G$. truttaceus were characterized in comparison to those of representative diadromous populations. The genetic character of the landlocked population: an almost complete lack of mtDNA diversity but without a concommitant decrease in nuclear gene heterozygosity, was hypothesized to be associated with incipient speciation. In this study, we present mtDNA and allozyme data from populations of $G$. auratus and $G$. tanycephalus and speculate that they have experienced similar events in their evolutionary history.

\section{Materials and methods}

Galaxias auratus (Lake Crescent $42^{\circ} 10^{\prime} \mathrm{S} 147^{\circ} 10^{\prime} \mathrm{E}$ ) and G. tanycephalus (Arthurs Lake $42^{\circ} 00^{\prime} \mathrm{S} 146^{\circ} 55^{\prime} \mathrm{E}$, Fig. $1)$ were collected by electrofishing. The mitochondrial genomes of $26 \mathrm{G}$. auratus and six G. tanycephalus were analysed. Nuclear allele frequencies were assayed from $40 \mathrm{G}$. auratus and six G. tanycephalus. The rarity and secretive habits of $G$. tanycephalus made it impractical to obtain a larger sample. The techniques used for the analysis of mtDNA and for the assay of alleles at 22 enzymic loci have been reported (Ovenden \& White, 1990).

The location of restriction sites recognized by 13 endonucleases (ApaLI, BamHI, BclI, BglII, BstEII, HindIII, NcoI, PstI, PvuII, SacII, SalI, XbaI,XhoI) were mapped within the mtDNA of $G$. auratus and $G$. tanycephalus. This was done by comparing the size and number of digestion products with those produced from G. truttaceus mtDNA (Ovenden \& White, 1990). Novel sites were mapped using the double digestion technique (Ovenden et al., 1992).

Haplotypes were a composition of the alphabetic restriction site morphs for each of the 13 restriction enzymes used. Restriction site presence and absence data were used to calculate sequence diversity (number of base substitutions per base pair) between each pair of haplotypes (Nei \& Li, 1979; Nei \& Tajima, 1983). In addition, mean intraspecific and interspecific diversity, with their appropriate standard errors (Nei \& Jin, 1989), were calculated for all genomes assayed. Nei's genetic distances and their standard errors were calculated from nuclear allele frequencies (Nei, 1972; Tomiuk \& Graur, 1988). The expected nuclear gene heterozygosity and its variance (Nei \& Roychoudhury, 1974), corrected for small sample size for G. tanycephalus (Nei, 1978), were calculated for each species. 


\section{Results}

\section{Mitochondrial DNA}

Three haplotypes were found amongst the six G. tanycephalus. Four fish possessed haplotype no. 2 (ABBADABAAAABB), while haplotypes no. 1 (ABBADABAAAABA) and no. 3 (ABBAEABAA$A A B B$ ) were found in one fish each. There were four G. auratus haplotypes. Haplotype no. 4 (ABBADADABAGBB) was the most common, being found in 22 fish. Two fish possessed haplotype no. 5 (ABCADAD$\mathrm{ABAGBB}$ ), and haplotype no. 6 (ABFADADABAGBB) and no. 7 (ABBADCDABAGBB) were found in one fish each. The restriction site composition of each haplotype is shown in Table 1 and the diversity between them in Table 2.

The sequences of the mitochondrial genomes of the 26 G. auratus samples were more similar to each other (mean intraspecific mitochondrial genome diversity across all genomes, $0.075 \pm 0.054$ per cent) than were those of the six $G$. tanycephalus samples $(0.146 \pm 0.119$ per cent; Table 3). In terms of interspecific mtDNA sequence diversity, the $G$. auratus samples were more similar to those of $G$. tanycephalus $(0.864 \pm 0.448$ per cent) than either was to the $G$. truttaceus sampled from stream habitats by Ovenden \& White (1990, Table 4).

The degree of restriction site similarity of $G$. tanycephalus and $G$. auratus to $G$. truttaceus (Ovenden \& White, 1990) suggests that their mtDNA is the same size. None of the $G$. tanycephalus and $G$. auratus restriction sites which were present in some, but not all, of the haplotypes fell within the $4260 \mathrm{bp}$ region, which was previously identified as being highly conserved in G. truttaceus (Ovenden \& White, 1990). No cases of intra-individual or inter-individual genome length heteroplasmy were recorded.

\section{Allozymes}

Of the 22 loci assayed in $G$. auratus and $G$. tanycephalus, 18 showed the same or similar allele frequencies in both species (Table 5). Genetic differences were detected between the remaining five loci. There was a fixed difference at the peptidase- $D$ locus. At the guanine deaminase locus, the alleles $G d a^{c}$ and $G d a^{e}$ were the most common in $G$. auratus while $G d a^{a}$ and $G d a^{d}$ were the most common in $G$. tanycephalus. At the malate dehydrogenase- 2 locus, allele $b$ was fixed in $G$. auratus, but present at low frequency in $G$. tanycephalus and accompanied by allele $a$. Three alleles were present at the phosphoglucomutase-1 locus $(a, c$ and $e$ ) while alleles $d$ and $e$ were present in G. tanycephalus.
Nuclear gene heterozygosity was $0.065 \pm 0.014$ (mean across all loci \pm variance) for $G$. auratus and $0.083 \pm 0.017$ for $G$. tanycephalus. Twelve or 55 per cent of the 22 loci were polymorphic in the sample of G. auratus, while 7 or 32 per cent of the loci were polymorphic in $G$. tanycephalus (Table 5). There was an average of 1.68 alleles per locus in the $G$. auratus sample and an average of 1.32 alleles per locus in the G. tanycepalus sample.

Nei's modified genetic distance between $G$. auratus and $G$. tanycephalus was $0.253 \pm 0.112$ ( \pm standard error). Unlike the mitochondrial genome, nuclear genome similarities indicated that $G$. tanycephalus was more closely related to stream populations of $G$. truttaceus (0.086 \pm 0.049 units) analysed by Ovenden \& White (1990), than to G. auratus. Galaxias auratus was separated by $0.149 \pm 0.079$ units of Nei's modified genetic distance from the stream populations of $G$. truttaceus analysed by Ovenden and White (Table 4).

\section{Discussion}

Extended evolution in an isolated habitat of finite size may be responsible for the lack of nuclear gene heterozygosity within $G$. auratus $(0.065)$ and $G$. tanycephalus $(0.083)$ relative to that of the recently formed lacustrine population of $G$. truttaceus. In the previous analysis by Ovenden \& White (1990), the lacustrine population of $G$. truttaceus had a similar amount of nuclear gene heterozygosity $(0.104)$ to their diadromous relatives (0.116) which occur in coastal streams. The limited resources available to these lake populations places an upper limit on population size, which does not affect genetic variability in the short term. This is shown by the large amount of allozyme heterozygosity retained from their diadromous ancestors by the recently formed lacustrine population of $G$. truttaceus. However, we suggest that genetic drift has led to a decrease in heterozygosity in $G$. auratus and $G$. tanycephalus which has not been augmented by immigration, as each population is reproductively isolated, or by mutation, as each population is too small.

Estimates of the amount of mtDNA variation within G. auratus $(0.075$ per cent) and $G$. tanycephalus $(0.146$ per cent) populations are significantly higher than that of the lacustrine $G$. truttaceus (effectively 0 per cent) previously analysed by Ovenden \& White (1990). mtDNA variation was probably reduced in lake populations of $G$. truttaceus by a severe, but brief, bottleneck event, possibly associated with the establishment of the population. Populations of $G$. auratus and $G$. tanycephalus may have experienced bottleneck events in the past, but their greater age and possible abundance have masked the possible influence of the 
Table 1 The presence (1) or absence $(0)$ of restriction sites in mitochondrial haplotypes in two species of galaxiids. The composite restriction morph of each haplotype is ABBADABAAAABA (1), ABBADABAAAABB (2),

ABBAEABAAAABB (3), ABBADADABAGBB (4), ABCADADABAGBB (5), ABFADADABAGBB (6) and ABBADCDABAGBB (7). The sites are described as the number of base pairs clockwise from the single $B g 1$ II site. Sites not previously identified amongst 216 G. truttaceus genomes (Ovenden \& White, 1990) are BclI sites 3, 4 and 5, XhoI site 6 and $X b a I$ site 5

\begin{tabular}{|c|c|c|c|c|c|c|c|c|}
\hline \multirow{2}{*}{$\begin{array}{l}\text { Site } \\
\text { position }\end{array}$} & & \multicolumn{3}{|c|}{ G. tanycephalus } & \multicolumn{4}{|c|}{ G. auratus } \\
\hline & & 1 & 2 & 3 & 4 & 5 & 6 & 7 \\
\hline BglII site 1 & 0 & 1 & 1 & 1 & 1 & 1 & 1 & 1 \\
\hline Pst $\mathrm{I}$ site 1 & 0 & 1 & 1 & 1 & 1 & 1 & 1 & 1 \\
\hline HindIII site 1 & 100 & 1 & 1 & 1 & 1 & 1 & 1 & 1 \\
\hline$B c I I$ site 2 & 613 & 0 & 0 & 0 & 0 & 1 & 0 & 0 \\
\hline HindIII site 2 & 984 & 1 & 1 & 1 & 1 & 1 & 1 & 1 \\
\hline BstEII site 1 & 1341 & 1 & 1 & 1 & 1 & 1 & 1 & 1 \\
\hline$X b a I$ site 2 & 1700 & 1 & 1 & 1 & 1 & 1 & 1 & 1 \\
\hline Pst I site 3 & 1707 & 1 & 1 & 1 & 1 & 1 & 1 & 1 \\
\hline$P v u I I$ site 1 & 2800 & 1 & 1 & 1 & 1 & 1 & 1 & 1 \\
\hline BamHI site 1 & 2883 & 1 & 1 & 1 & 1 & 1 & 1 & 1 \\
\hline SalI site 3 & 3088 & 1 & 1 & 1 & 1 & 1 & 1 & 1 \\
\hline NcoI site 1 & 3100 & 0 & 0 & 0 & 1 & 1 & 1 & 1 \\
\hline Ncol site 2 & 3300 & 1 & 1 & 1 & 0 & 0 & 0 & 0 \\
\hline Xhol site 2 & 3700 & 1 & 1 & 1 & 1 & 1 & 1 & 1 \\
\hline NcoI site 3 & 4183 & 1 & 1 & 1 & 1 & 1 & 1 & 1 \\
\hline SalI site 4 & 4452 & 1 & 1 & 1 & 1 & 1 & 1 & 1 \\
\hline Xhol site 3 & 4825 & 0 & 1 & 1 & 1 & 1 & 1 & 1 \\
\hline Xhol site 4 & 4888 & 1 & 1 & 1 & 1 & 1 & 1 & 1 \\
\hline$P v u$ II site 3 & 5117 & 1 & 1 & 1 & 1 & 1 & 1 & 1 \\
\hline$B s t$ EII site 3 & 5187 & 1 & 1 & 1 & 1 & 1 & 1 & 1 \\
\hline NcoI site 4 & 5733 & 1 & 1 & 1 & 1 & 1 & 1 & 1 \\
\hline HindIII site 4 & 5934 & 1 & 1 & 1 & 1 & 1 & 1 & 1 \\
\hline$P v u$ II site 5 & 7018 & 0 & 0 & 0 & 1 & 1 & 1 & 1 \\
\hline SalI site 6 & 7475 & 1 & 1 & 1 & 1 & 1 & 1 & 1 \\
\hline SalI site 5 & 7540 & 0 & 0 & 0 & 1 & 1 & 1 & 1 \\
\hline$B s t$ EII site 5 & 7687 & 1 & 1 & 1 & 1 & 1 & 1 & 1 \\
\hline SacII site 3 & 9094 & 1 & 1 & 1 & 1 & 1 & 1 & 1 \\
\hline HindIII site 5 & 9180 & 1 & 1 & 1 & 1 & 1 & 1 & 1 \\
\hline ApaLI site 1 & 9616 & 1 & 1 & 1 & 1 & 1 & 1 & 1 \\
\hline$X b a I$ site 3 & 9626 & 1 & 1 & 1 & 1 & 1 & 1 & 1 \\
\hline XhoI site 6 & 9812 & 1 & 1 & 1 & 1 & 1 & 1 & 1 \\
\hline$X b a I$ site 4 & 9853 & 1 & 1 & 1 & 1 & 1 & 1 & 1 \\
\hline ApaLI site 2 & 10709 & 1 & 1 & 1 & 1 & 1 & 1 & 1 \\
\hline SacII site 4 & 10950 & 1 & 1 & 1 & 1 & 1 & 1 & 1 \\
\hline Pst I site 6 & 11412 & 1 & 1 & 1 & 1 & 1 & 1 & 1 \\
\hline$P v u$ II site 6 & 11876 & 1 & 1 & 1 & 1 & 1 & 1 & 1 \\
\hline HindIII site 6 & 11954 & 1 & 1 & 1 & 1 & 1 & 1 & 0 \\
\hline HindIII site 7 & 13075 & 1 & 1 & 1 & 1 & 1 & 1 & 1 \\
\hline$B c I I$ site 4 & 13143 & 0 & 0 & 0 & 0 & 0 & 1 & 0 \\
\hline BstEII site 6 & 13347 & 1 & 1 & 0 & 1 & 1 & 1 & 1 \\
\hline HindIII site 8 & 14018 & 1 & 1 & 1 & 1 & 1 & 1 & 1 \\
\hline$X b a I$ site 5 & 14234 & 1 & 1 & 1 & 1 & 1 & 1 & 1 \\
\hline$B c l \mathrm{I}$ site 5 & 15260 & 1 & 1 & 1 & 1 & 1 & 0 & 1 \\
\hline NcoI site 7 & 16231 & 1 & 1 & 1 & 1 & 1 & 1 & 1 \\
\hline
\end{tabular}


Table 2 The sequence diversity (number of base substitutions per base pair, above diagonal) and standard errors (below diagonal) between three G. tanycephalus and four G. auratus haplotypes. Haplotypes are numbered in Table 1

\begin{tabular}{llllllll}
\hline G. tanycephalus, 1 & - & 0.00218 & 0.00445 & 0.01092 & 0.01302 & 0.01550 & 0.01337 \\
G. tanycephalus, 2 & 0.00219 & - & 0.00218 & 0.00856 & 0.01064 & 0.01302 & 0.01092 \\
G. tanycephalus, 3 & 0.00319 & 0.00219 & - & 0.01092 & 0.01302 & 0.01550 & 0.01337 \\
G. auratus, 4 & 0.00504 & 0.00439 & 0.00504 & - & 0.00202 & 0.00412 & 0.00207 \\
G. auratus, 5 & 0.00553 & 0.00491 & 0.00553 & 0.00203 & - & 0.00614 & 0.00412 \\
G. auratus, 6 & 0.00613 & 0.00553 & 0.00613 & 0.00295 & 0.00361 & - & 0.00630 \\
G. auratus, 7 & 0.00568 & 0.00504 & 0.00568 & 0.00208 & 0.00295 & 0.00371 & - \\
\hline
\end{tabular}

Table 3 Mitochondrial and nuclear DNA variability within three species of galaxiid fish

\begin{tabular}{llrlr}
\hline & $\begin{array}{l}\text { Intraspecific } \\
\text { mtDNA diversity } \\
(\%)\end{array}$ & \multicolumn{1}{l}{$\begin{array}{l}\text { Nuclear gene } \\
\text { heterozygosity }\end{array}$} & $n$ \\
\hline G. auratus & 0.075 & 26 & 0.065 & 40 \\
G. tanycephalus & 0.146 & 9 & 0.083 & 6 \\
G. truttaceus* & 0.624 & 150 & 0.116 & 82 \\
G. truttaceus & 0 & 66 & 0.104 & 40 \\
\hline
\end{tabular}

*Sampled from 12 (mtDNA) or two (nuclear DNA) coastal drainages in southeastern Australia (Ovenden \& White, 1990).

$\ddagger$ Sampled from four (mtDNA) or one (nuclcar DNA) central Tasmanian lake (Ovenden \& White, 1990).

Table 4 The number of mtDNA base substitutions per base pair (corrected for intraspecific diversity, above diagonal) and Nei's modified genetic distance (below diagonal) between three species of galaxiid fish

\begin{tabular}{llll}
\hline & G. auratus & G. tanycephalus & G. truttaceus \\
\hline G. auratus & - & $0.864 \%$ & $1.915 \%$ \\
G. tanycephalus & 0.253 & - & $1.025 \%$ \\
G. truttaceus* & 0.149 & 0.086 & - \\
\hline
\end{tabular}

*Sampled from 12 (mtDNA) or two (nuclear DNA) coastal drainages in south-eastern Australia (Ovenden \& White, 1990).

event upon mtDNA diversity. Interestingly, the most abundant present day population, G. auratus, does not have the greatest mtDNA diversity.

Speciation following landlocking of diadromous populations of $G$. truttaceus is the most tenable explanation of the evolution of $G$. auratus and $G$. tanycephalus, given their biogeography and phenotypic relationship to $G$. truttaceus and the tendency of $G$. truttaceus to intrude gradually into inland waters (McDowall, 1972; Andrews, 1976; Fulton, 1978). The formation of lacustrine populations of (j. truttaceus via landlocking, and its genetic implications, have previously been studied by Ovenden \& White (1990).

The habitats of $G$. auratus and $G$. tanycephalus (Lakes Sorell and Crescent and Arthurs and Woods Lakes) are more ancient than the shallow, post-glacial lakes currently occupied by $G$. truttaceus. The exact ages of the older lakes are unknown but it is likely that they were formed by geomorphological activity less than 100,000 years ago and occur outside the areas affected by the Pleistocene glaciation (Davies, 1974). While the ancestors of the lacustrine G. truttaceus may have become landlocked 3000-7000 years ago (Ovenden \& White, 1990), it is possible that the ancestors of $G$. auratus and $G$. tanycephalus may have invaded the precursors of their current habitats as long as 100,000 years ago.

Arthurs and Woods Lakes drain to the north while Lakes Sorell and Crescent flow to the south. It is possible, however, that Arthurs and Woods Lakes previously drained southwards as they share an endemic galaxiid genus (Paragalaxias; McDowall \& Fulton, 1978) and a syncarid crustacean species (Paranaspides lacustris; Fulton, 1982) with the nearby Great Lake which currently drains southward. The direction of drainage of Arthurs and Woods Lakes may have been affected by tilting of strata in response to the melting of 


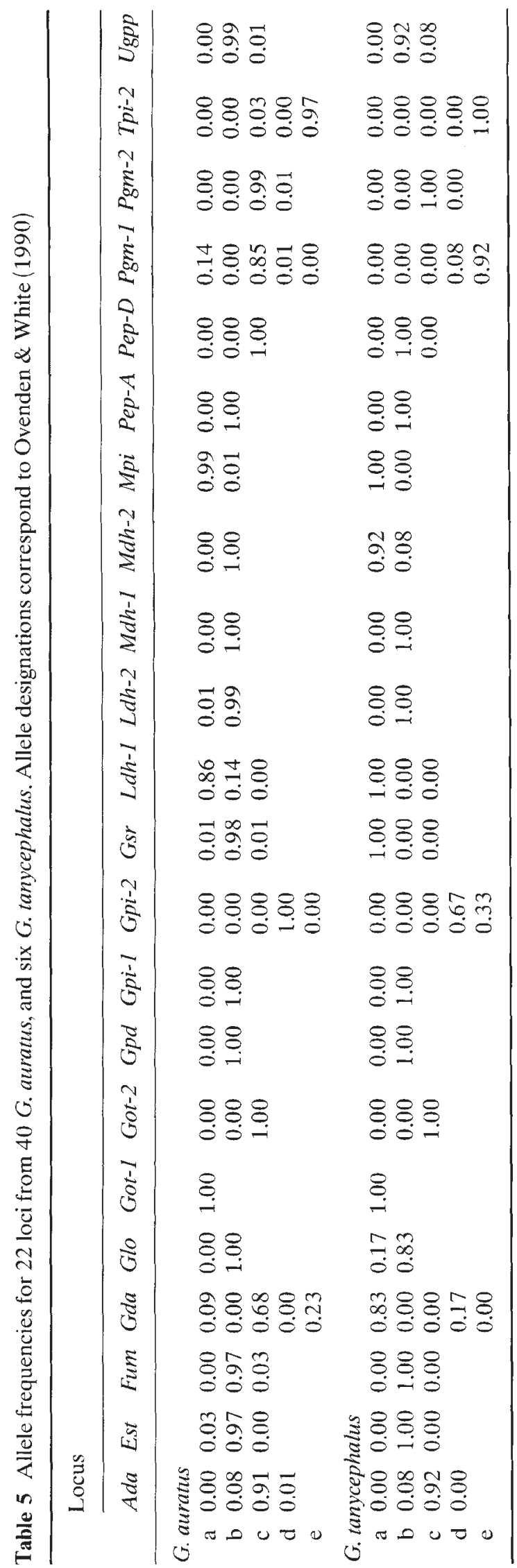

the ice-sheets at the end of the glaciation (Banks, 1973) or to tectonic activity (Davies, 1965).

The ancestors of $G$. auratus and $G$. tanycephalus may have invaded inland freshwater drainages from the south, when the primordial Lakes Sorell and Crescent and Arthurs and Woods Lakes were the endpoints of southern drainages. A permanent drop in the water table, followed by the tilting of Arthurs and Woods Lakes to the north may have initiated the reproductive isolation of the ancestral $G$. auratus and $G$. tanycephalus. Alternatively, the primordial lakes may have been invaded independently from both the south and the north after they attained the direction of their present day drainage.

The evolutionary relationship of $G$. auratus and $G$. tanycephalus to G. truttaceus, and hence the most likely landlocking scheme, cannot be resolved in this instance with phylogenetic techniques. Pamilo \& Nei (1988) warn that phylogenetic trees constructed from DNA sequences at a genetic locus (mtDNA) do not necessarily agree with the evolutionary pathway of the species. The most common cause of this discrepancy is the genetic polymorphism of the ancestral species and drift associated with bottlenecks across a short span of evolutionary time. All three conditions exist within the $G$. auratus, G. tanycephalus and $G$. truttaceus assemblage. Another problem for the testing of alternative topologies between G. auratus, G. tanycephalus and $G$. truttaceus is the lack of suitable outgroups. While allozyme data do exist for most other galaxiid species ( $R$. W. G. White \& J. R. Ovenden, in preparation), the next most closely related galaxiid to this triad is $G$. olidus, which shares virtually no mtDNA restriction sites with them (J. R. Ovenden, unpublished observations).

A considerable amount of mtDNA sequence divergence has accumulated between diadromous populations of G. truttaceus analysed by Ovenden \& White (1990) and either $G$. auratus (1.915 per cent) or $G$. tanycephalus (1.025 per cent, Table 3 ). This magnitude of mtDNA divergence is similar to that cited by Avise et al. (1987) for most pairs of closely related vertebrate species. By way of contrast, Nei's genetic distances separating the species pairs ( $G$. auratus and $G$. truttaceus, $0.149 ; G$. tanycephalus and G. truttaceus, $0.086)$ are among the smallest reported between congeneric species of fish (Avise \& Aquadro, 1982). The abrupt and permanent effect of bottlenecks upon the intraspecific mtDNA diversity of $G$. auratus and $G$. tanycephalus in their confined lake habitat may have emphasized mitochondrial, but not nuclear, DNA divergence between them and G. truttaceus.

If the ancestral populations of $G$. auratus and $G$. tanycephalus were derived from an inland invasion of diadromous $G$. truttaceus from the south, it is possible 
that gene flow between the primitive landlocked lake populations continued after their connection with the coastal drainages was severed. Gene exchange amongst primitive lake populations also may have occurred following independent inland invasions from the north and south, especially if drainage patterns were in a state of flux. However, the magnitude of net mtDNA divergence (0.864 per cent), and notably Nei's genetic distance ( 0.253 ), between $G$. auratus and G. tanycephalus compared to that between them and the populations of G. truttaceus analysed by Ovenden and White (1990, Table 3), is large enough to suggest that the lake species have been reproductively isolated during most of their evolutionary history.

The mitochondrial and allozyme genetics of $G$. auratus and $G$. tanycephalus are consistent with their having experienced evolution in reproductive isolation with a finite population size. Their close genetic relationship to G. truttaceus, in both the mitochondrial and nuclear genomes, does not conflict with the hypothesis of their possible speciation from landlocked G. truttaceus ancestors. Furthermore, it is conceivable that the pattern of mitochondrial and nuclear DNA found in $G$. auratus and G. tanycephalus is the logical extension of evolution in lacustrine isolation of which the lake population of $G$. truttaceus is an example.

\section{Acknowledgements}

We would like to thank the University of Tasmania Research Committee, the Australian Research Grants Committee (grant no. A185/16061) and the Australian Research Council (grant no. A18715920) for financial support. Persons whose assistance was invaluable to the successful completion of this project include Wayne Kelly, Stephanie Kalish, Jenny Jarrett, Paul Humphries, Peter Davies, Wayne Fulton and Andrew Sanger. We appreciate the comments made by the referee on the manuscript.

\section{References}

ANDREWS, A. P. 1976. A revision of the family Galaxiidae (Pisces) in Tasmania. Aust. J. Mar. Freshw. Res., 27, 297-349.

AVISE, J. C. AND AQUADRO, C. F. 1982. A comparative summary of genetic distances in the vertebrates. Patterns and correlations. Evol. Biol., 15, 151-185.

AVISE, J. C., ARNOLD, J., BALL, R., BERMINGHAM, E., LAMB, T., NEIGEL, J. E. REEB, C. A. AND SAUNDERS, N. C. 1987. Intraspecific phylogeography: the mitochondrial DNA bridge between population genetics and systematics. Ann. Rev. Ecol. Syst., 18, 489-522.

AVISE, J. C., NEIGEL, J. E. AND ARNOLD, J. 1984. Demographic influences on mitchondrial DNA lineage survivorship in animal populations. J. Mol. Evol., 20, 99-105.
BANKS, M. R. 1973. Geomorphology. In: Banks, M. R. (ed.) The Lake Country of Tasmania, Royal Society of Tasmania, Hobart, pp. 55-60.

BERMINGHAM, E. AND AVISE, J. C. 1986. Molecular zoogeography of freshwater fishes in the southeastern United States. Genetics, 113, 939-965.

BERRA, T. M. 1981. An Atlas of Distribution of Freshwater Fish Families of the World. University of Nebraska Press, Lincoln and London.

BIRKY, C. W., MARUYAMA, T. AND FUERST, P. 1983. An approach to population and evolutionary genetic theory for genes in mitochondria and chloroplasts, and some results. Genetics, 103, 513-527.

BROWN, W. M. 1985. The mitochondrial genome of animals. In: MacIntyre, R. J. (ed.) Molecular Evolutionary Genetics. Plenum, New York, pp. 95-130.

CARSON, H. L. 1968. The population flush and its genetic consequences. In: Lewontin, R. C. (ed.), Population Biology and Evolution, Syracuse University Press, New York, pp. 123-137.

DAVIES, J. L. 1965. Landforms. In: Davies, J. L. (ed.) Atlas of Tasmania. Lands and Survey Department, Hobart, pp. 19-25.

DAVIES, J. L. 1974. Geomorphology and quaternary environments. In: Williams, W. D. (ed.) Biogeography and Ecology in Tasmania, W. Junk, The Hague, pp. 17-27.

FULTON, w. 1978. A description of a new species of Galaxias (Pisces: Galaxiidae) from Tasmania. Aust. J. Mar. Freshw. Res., 29, 109-116.

FULTON, w. 1982. Notes on the distribution and life cycle of Paranaspides lacustris Smith (Crustacea: Syncarida). Bull. Aust. Soc. Lim., 8, 23-25.

GYLLENSTEN, U., WHARTON, D. AND WILSON, A. C. 1985. Maternal inheritance of mitochondrial DNA during backcrossing of two species of mice. J. Hered., 76, 321-324.

HUMPHRIES, P. 1989. Variation in the life history of diadromous and landlocked populations of the spotted galaxias, Galaxias truttaceus Valenciennes, in Tasmania. Aust. J. Mar. Freshw. Res., 40, 501-518.

JOHNSON, C. R., RATKOWSKY, D. A. AND WHITE, R. W. G. 1983. Multivariate analysis of the phenotypic relationships of the species of Paragalaxias and Galaxias (Pisces: Galaxiidae) in Tasmania. J. Fish. Biol., 23, 49-63.

JOHNSON, C. R., WHITE, R. W. G. AND BICK, Y. A. E. 1981. Cytotaxonomy of seven species of Galaxias (Pisces: Galaxiidae) in Tasmania. Genetica, 56, 17-21.

LANSMAN, R. A., SHADE, R. O., SHAPIRA, J. F. AND DANIEL, S. W. 1983. Critical experimental test of the possibility of "paternal leakage' of mitochondrial DNA. Proc. Natl. Acad. Sci., U.S.A., 80, 1969-1971.

McDOWALL, R. M. 1972. The species problem in freshwater fishes and the taxonomy of diadromous and lacustrine populations of Galaxias maculatus. J. Roy. Soc. N.Z., 2, 325-367.

McDOWALL, R. M. AND FRANKENBERG, R. S. 1981. The galaxiid fishes of Australia (Salmoniformes: Galaxiidae). Rec. Aust. Mus., 33, 443-605.

McDOWALL, R. M. AND FULTON, w. 1978. A revision of the genus Paragalaxias Scott (Salmoniformes: Galaxiidae). Aust. J. Mar. Freshw. Res., 29, 93-108. 
NEI, M. 1972. Genetic distance between populations. Am. Nat., 106, 283-292.

NEI, M. 1978. Estimation of average heterozygosity and genetic distance from a small number of individuals. Genetics, 89, 583-590.

NEI, M. AND JIN, L. 1989. Variances of the average numbers of nucleotide substitutions within and between populations. Mol. Biol. Evol., 6, 290-300.

NEI, M. AND LI, W.-H. 1979. Mathematical model for studying genetic variation in terms of restriction endonucleases. Proc. Natl. Acad. Sci., U.S.A., 76, 5269-5273.

NEI, M. AND TAJIMA, F. 1983. Maximum likelihood estimation of the number of nucleotide substitutions from restriction sites data. Genetics, 105, 207-217.

NEI, M. AND ROYCHOUDHURY, A. K. 1974. Sampling variances of heterozygosity and genetic distance. Genetics, 76, 379390.

OVENDEN, J. R. AND WHITE, R. W. G. 1990. Mitochondrial and allozyme genetics of incipient speciation in a landlocked population of Galaxias truttaceus (Pisces: Galaxiidae). Genetics, 124, 701-716.

OVENDEN, J. R., BYWATER, R. AND WHITE, R. W. G. 1992. A program for the estimation of restriction endonuclease site positions from restriction fragment size and number - an aid for mitochondrial DNA analysis. J. Hered. 83, 240-241.

OVENDEN, J. R., WHITE, R. W. G. AND SANGER, A. C. 1988. Evolutionary relationships of Gadopsis spp. inferred from restriction enzyme analysis of their mitochondrial DNA. $J$. Fish Biol., 32, 137-148.

PAMILO, P. AND NEI, M. 1988. Relationship between gene trees and species trees. Mol. Biol. Evol., 5, 568-583.

TOMIUK, J. AND GRAUR, D. 1988. Nei's modified genetic identity and distance measures and their sampling variances. Syst. Zool., 37, 156-162.

WILSON, A. C., CANN, R. L., CARR, S. M., GEORGE, Jr., M., GYLLENSTEN, U. B., HELM-BYCHOWSKI, K. M., HIGUCHI, R. G., PALUMBI, S. R., PRAGER, E. M., SAGE, R. D. AND STONEKING, M. 1985. Mitochondrial DNA and two perspectives on evolutionary genetics. Biol. J. Linn. Soc., 26, 375-400. 